УДК 65.012 .654

JEL Classification: D83, Y90

КАЛІНЕСКУ Т. В.

\title{
ОБЛІКОВО-ФІНАНСОВІ МЕХАНІЗМИ СОЦІАЛЬНО-ЕКОНОМІЧНОГО РОЗВИТКУ СУБ'СКТІВ ГОСПОДАРЮВАННЯ
}

\author{
DOI: $10.32620 /$ cher.2021.1.06
}

Постановка проблеми. Прагнення щодо розв'язання різних інтересів суспільства, суб'єктів господарювання та індивідуумів доводять, що у кінцеву підсумку вони приводять до визначення прогресу у зростанні доходів і прибутку, досягненні високого рівня благополуччя суспільства та кожного його громадянина. Тому виникає потреба у грунтовному дослідженні обліково-фінансового інструментарію, що наповнює механізми сучасного соціально-економічного розвитку суб'єктів господарювання. Мета дослідження спрямована на пошук нових механізмів обліково-фінансового контролю, що визначають соціально-економічний розвиток суб'єктів господарювання з метою задоволення потреб суспільства на локальному і глобальному рівнях. Методологічною основою дослідження стали сучасні нормативно-правові та законодавчі аспекти щодо стійких перспектив соціально-економічного розвитку суб'єктів господарювання. В проведених дослідженнях використані методи діалектики, способи і принципи наукового пізнання, інструменти економічного аналізу задля поліпшення обліково-фінансових механізмів соціально-економічного розвитку в умовах постійно змінюваних знань. Основною гіпотезою дослідження стало припущення щодо можливості удосконалення обліковофінансового механізми соціально-економічного розвитку суб'єктів господарювання з метою досягнення визначених стратегічних орієнтирів у нестабільному оточуючому середовищі. Виклад основного матеріaлy. У статті досліджуються методики конструювання обліково-фінансових механізмів соціальноекономічного розвитку; методи ідентифікації проблем, що постійно з'являються в оточуючому середовищі господарювання; принципи обліку і виміру кумулятивних ефектів; технології визначення наслідків вибору різних заходів і важелів щодо соціально-економічного розвитку у довгостроковій перспективі. Проаналізовані основні орієнтири, що визначають стабільну діяльність суб'єкта та обгрунтовано склад обліково-фінансового механізму, його мотивуючих і стимулюючих важелів щодо прогресивного соціально-економічного розвитку суб'єктів господарювання. Оригінальність та практична значимість дослідження підтверджується запропонованим складом механізму соціально-економічного розвитку, що дозволить зосередитись на контролі та обліку головних орієнтирів ефективної діяльності та оцінити тенденції його стійкого соціально-економічного зростання відповідно до загальновизнаних міжнародних стандартів та рівня життєздатності національної економіки. Висновки та перспективи подальших досліджень. Доведено, що головними складовими обліково-фінансової діяльності суб'єктів господарювання у механізмі сучасного соціально-економічного розвитку, слід вважати: формування системи обліку фінансово-економічних показників, запровадження моніторингу та оцінювання розривів між тактичними й стратегічними орієнтирами; врахування масштабів впливу інноваційних дифузій на напрями соціально-економічного розвитку; налаштування на нові мотиви й стимули трансформування соціально-економічних систем; оцінювання наслідків впливу оточуючого середовища та розробка заходів корегування орієнтирів відповідно досягненням економіки знань; цифровізація суспільних комунікацій та зацікавлених зв'язків суб'єктів; управління інноваційною рефлексією соціально-економічного розвитку суб'єктів господарювання. Подальші дослідження будуть спрямовані на пошук та удосконалення сучасних інформаційно-комунікаційних технологій щодо інноваційної дифузії, надбання та розповсюдження найкращих облікових практик та фінансових оцінювань результатів соціально-економічного розвитку суб'єктів господарювання в умовах постійно змінюваних знань.

Ключові слова:

суб'єкти господарювання, соціально-економічний розвиток, обліково-фінансовий механізм.

${ }^{1}$ Калінеску Тетяна Василівна, д-р екон. наук, професор, завідувач кафедри фінансів, обліку і оподаткування, Національний аерокосмічний університет ім. М. Є. Жуковського «Харківський авіаційний інститут», м. Харків, Україна.

Calinescu Tetyana, Doctor of Economic Sciences, Professor, Head of Finance, Accounting and Taxation Department, National Aerospace University «Kharkiv Aviation Institute», Kharkiv, Ukraine.

ORCID ID: 0000-0003-4919-5788

e-mail: tetyana.calinescu@gmail.com 


\section{REGISTRATION-FIINANCIAL MECHANISMS OF SOCIO-ECOMONIC DEVELOPMENT THE SUBJECTS OF BUSINESS}

Raising of problem. Aspirations prove in relation to the decision of different interests of society, subjects of business and individuals, that in eventual to the result they brings to determination of fate an increase over of profits and income, achievement of high level of prosperity the society and each its citizen. Therefore there is a requirement in ground research of registration-financial tool that fills the mechanisms of modern socio-economic development the subjects of business. A research aim is direct on the search of new mechanisms of registration-financial control that are evaluating the socio-economic development the subjects of business with the aim of satisfaction the necessities of society on local and global levels. The methodological basis of research became modern normatively-legal and a legislative aspect in relation to the proof prospects of socio-economic development the subjects of business. In the conducted researches was used methods of dialectics, methods and principles of scientific cognition, instruments of economic analysis for the improvement of registration-financial mechanisms of socio-economic development in the conditions of constantly changeable knowledge. The basic hypothesis of research became supposition of possibility improvement registration-financial mechanisms of socio-economic development the subjects of business with the aim of achievement the certain strategic reference-points in an unstable environment. $E x$ position of basic material. In the article was investigated methodologies of constructing the registrationfinancial mechanisms of socio-economic development, methods of authentication the problems that constantly appear in the environment of business, principles of account and measuring of cumulative effects, technologies of determination the consequences of choice the different measures and levers in relation to socio-economic development in a long-term prospect. It was analyzed basic reference-points, that determine stable activity of subject and composition of registration-financial mechanism, explaining and stimulant levers is reasonable in relation to progressive socio-economic development the subjects of business. Originality and practical meaningfulness of research are confirmed by the offered composition of socioeconomic mechanism of development that will allow to concentrate on control and account of main reference-points of effective activity and estimate the tendencies of its proof socio-economic increase in accordance with confessedly international standards and level of viability the national economy. Conclusions and prospects of further researches. It was well-proven that in registration-financial activity the subjects of business at determination of effective mechanisms of modern socio-economic development follows main levers to consider as: forming of the system of account the financial-economical indexes, input of monitoring and evaluation of breaks between tactical and strategic reference-points, account of scales of influence the innovative diffusions on directions of socio-economic development, tuning on new motivation and stimuli of socio-economic systems transformation, evaluation of consequences the influence of environment and development of propositions in relation to correct and changes of reference-points according to the achievements of knowledge economy, digitalization of public communications and personal interest of subjects; management the innovative reflection of socio-economic development the subjects of business. Further researches will direct to the search and improvement of modern informatively-communication technologies in relation to innovative diffusion, acquisition and distribution of the best registration practices and financial evaluations of results the socio-economic development the subjects of business in the conditions of constantly changeable knowledge.

Key words:

subjects of business, socio-economic development, registration-financial mechanism.

\section{УЧЕТНО-ФИНАНСОВЫЕ МЕХАНИЗМЫ СОЦИАЛЬНО-ЭКОНОМИЧЕСКОГО РАЗВИТИЯ СУБЪЕКТОВ ХОЗЯЙСТВОВАНИЯ}

Постановка проблемы. Стремления, связанные с решением разных интересов общества, субъектов хозяйствования и индивидуумов доказывают, что в конечном итоге они приводят к определению прогресса возрастания доходов и прибыли, достижения высокого уровня благополучия общества и каждого его гражданина. Поэтому возникает потребность в основательном исследовании учетно-финансового инструментария, который наполняет механизмы современного социальноэкономического развития субъектов хозяйствования. Цель исследования направлена на поиск новых механизмов учетно-финансового контроля, которые определяют социально-экономическое развитие субъектов хозяйствования с целью удовлетворения потребностей общества на локальном и глобальном уровнях. Методологической основой исследования стали современные нормативно-правовые и законодательные аспекты получения устойчивых тенденций в социально-экономическом развитии субъектов хозяйствования. В проведенных исследованиях использованные методы диалектики, спо- 
собы и принципы научного познания, инструменты экономического анализа для улучшения учетнофинансовых механизмов социально-экономического развития в условиях постоянно изменяющихся знаний. Основной гипотезой исследования стало предположение относительно возможности усовершенствования учетно-финансового механизма социально-экономического развития субъектов хозяйствования с целью достижения определенных стратегических ориентиров в нестабильной окружающей среде. Изложение основного материала. В статье исследуются методики конструирования учетно-финансовых механизмов социально-экономического развития; методы идентификации проблем, которые постоянно появляются в окружающей среде хозяйствования; принципы учета и измерения кумулятивных эффектов; технологии определения последствий выбора разных способов и рычагов воздействия на социально-экономическое развитие в долгосрочной перспективе. Проанализированы основные ориентиры, которые определяют стабильную деятельность субъекта и обоснован состав учетно-финансового механизма, мотивирующих и стимулирующих рычагов прогрессивного социально-экономического развития субъектов хозяйствования. Оригинальность и практическая значимость исследования подтверждается предложенным составом механизма социальноэкономического развития, который позволит сосредоточиться на контроле и учете главных ориентиров эффективной деятельности и оценить тенденции его устойчивого социально-экономического роста в соответствии с общепризнанными международными стандартами и уровнем жизнеспособности национальной экономики. Bыводы и перспективы дальнейших исследований. Доказано, что действенными рычагами учетно-финансовой деятельности субъектов хозяйствования, запускающими механизм современного социально-экономического развития, следует считать: формирование системы учета финансово-экономических показателей; введение мониторинга и оценки разрывов между тактическими и стратегическими ориентирами; учет масштабов влияния инновационных диффузий на направления социально-экономического развития; формирование новых мотивов и стимулов трансформации социально-экономических систем; оценка последствий влияния окружающей среды и разработка мероприятий по корректировке ориентиров относительно достижений экономики знаний; цифровизация общественных коммуникаций и заинтересованных связей субъектов; управление инновационной рефлексией социально-экономического развития субъектов хозяйствования. Дальнейшие исследования будут направлены на поиск и усовершенствование современных информационно-коммуникационных технологий осуществления инновационной диффузии, приобретения и распространения наилучших учетных практик и финансовых оценок результатов социально-экономического развития субъектов хозяйствования, в условиях постоянно изменяющихся знаний.

\section{Ключевые слова:}

субъекты хозяйствования, социально-экономическое развитие, учетно-финансовый механизм.

Постановка проблеми. Провідною метою соціально-економічного розвитку є прагнення щодо розв'язання різних інтересів, суспільства, підприємництва (суб'єктів господарювання) та індивідуалів (громадян суспільства). Проте всі ці інтереси у кінцеву вигляді зводяться до зростання долі суспільного багатства (чи прибутку), досягнення високого рівня благополуччя суспільства та кожного його громадянина.

Якщо зосередитися тільки на суб'єктах господарювання, то обліково-фінансові аспекти соціально-економічного розвитку мають бути зосереджені на контролі щодо зростання капіталу, досягнення більшого прибутку, підвищенням рентабельності і обсягів виробництва якісного продукції (чи надання таких же послуг) [1, с. $104-111]$. Проте усі ці показники $є$ синтетичними поняттями, що об'єднують у собі багато різнорідних цілей, понять та інтересів, що мають змінюватися одночасно у позитивному напрямі, якщо ставиться ціль щодо їх максимізації.

Дане дослідження здійснюється в рамках тематики науково-технічних досліджень «Обліково-фінансові механізми інноваційної взаємодії суб'єктів господарювання в контексті трансформації економіки знань та соціально-поведінкових обмежень», що виконується на кафедрі фінансів обліку і оподаткування національного аерокосмічного університету ім. М.Є. Жуковського «Харківський авіаційний інститут» (державний реєстраційний номер 012 1U108324). Тому виникає потреба у грунтовному дослідженні обліково-фінансового інструментарію, що наповнює механізми сучасного розвитку суб'єктів господарювання, та оцінюванні різних проявів соціально-економічних обмежень 3 метою подальшого мотивування українського бізнесу до інноваційних перетворень відповідно тактичних і стратегічних орієнтирів ро- 
звитку національної економіки та благополуччя суспільства.

Аналіз останніх досліджень і публікацій. Наразі більшість сучасні дослідниківекономістів [1, с. 109 - 110] дотримуються раціоналістичної концепції, що пов'язана 3 роботами А. Сміта [2], та доводять, що сучасний розвиток підприємці намагаються звести до оптимізації усіх параметрів, котрі приводять всі різноспрямовані (іноді протилежні) соціально-економічні дії до ідентичних позитивних, грунтуючись на двох основних формах раціональності:

1) максимізації функцій корисності шляхом розподілу ресурсів між різними сферами діяльності, що вимагає постійної оптимізації;

2) обмеженні раціональності, що показує як суб'єкти можуть діяти раціонально в межах встановлених норм поведінки, суджень та існуючої невизначеності, що породжує помилкові дії.

Окрім того, сам розвиток, слід сприймати як прояв нерівномірності, що підкорюються прояву законів [1, с. 126]:

взаємозв'язку технологічної необхідності з економічними інтересами, завдяки чому можливий розвиток у будь-якій сфері, особливо у соціальній. Кожний взаємозв'язок можна розглядати як співпрацю [3, с. 151-165], що є обов'язковою ознакою розвитку. Завдяки Інтернету та соціальним мережам всі взаємозв'язки стають дедалі еластичнішими i глобальнішими. Проте найпотужнішою силою розвитку є реалізація власних інтересів. Тому всі інші когнітивні умови (у томи числі рівень розвитку технологічної складової) служать загальними благами та інтересами;

ускладнення суспільно-економічної структури, за яким додавання нового елементу не змінює, а доповнює існуючі. Тому об'єднання у групи різних соціальноекономічних потенціалів суб' єктів господарювання для розв'язання поставлених цілей (реалізації власних інтересів) і протидії (запобіганню) руйнівних наслідків впливу зовнішніх факторів (у тому числі глобальних) $\epsilon$ потужним механізмом щодо розв'язання певних проблем на локальному рівні [3, с. 165181]. Безумовно, у глобалізованому суспільстві виникає тенденція до збільшення таких об'єднань. I тут слід збалансовувати індивідуальні інтереси та стратегічні цілі, виходячи 3 того, що: оптимум в будь-якому напрямі може бути досягнутий завдяки диспропорцій у інших;

зміни у одній плоскості - приводять до інших змін у різних сферах соціальноекономічних відношень.

Тому, підводячи підсумок різним аспектам досліджень, що вже напрацьовані навколо визначення критеріїв, інструментів, мотивів, стимулів та важелів соціальноекономічного розвитку, можна означити мету статті - пошук таких механізмів обліковофінансового контролю, що спрямовані на соціально-економічний розвиток суб'єктів господарювання 3 метою задоволення потреб суспільства на локальному і глобальному рівнях.

Виклад основного матеріалу дослідження. На сучасному етапі розвитку економіки всі обліково-фінансові механізми можна звести до пошуку найбільш точних методів ідентифікації проблем, що постійно з'являються в оточуючому середовищі господарювання. I тут слід надавати перевагу обліку і виміру кумулятивних [3, с. 182-201] (синергетичних) ефектів. Те що здається ефективним на індивідуальному рівні, може викликами катастрофічні наслідки на глобальному рівні i, навпаки, - раціональний вибір одного заходу у довгостроковій перспективі може привести до ірраціональності у інших аспектах діяльності. Це стосується як фінансово-економічних аспектів господарської діяльності, так і іiі соціальних, екологічних та суспільно-гуманітарних складових. Тобто кожен суб'єкт господарювання має спрямовувати свою діяльність на глобальну чи комплементарну єдність. Звідси нові технології, нові ідеї та постійні новоутворення, це той елемент соціально-економічного розвитку, який слід поєднувати з існуючим станом (рівнем) своїх досягнень. Бо прагнення до інтеграції може протидіяти національній ідентифікації та пропагуванню інших цінностей, що не сприймається сучасним суспільством на локальному (на рівні суб' єкта господарювання), регіональному чи національному рівнях. У цій ситуації дуже важливо знайти такі інструменти, щоб дозволяли збалансовувати (чи нівелювати) ті диспропорції у розвитку для досягнення усіх поставлених стратегічних завдань.

Наразі, кожен суб'єкт господарювання має вивіряти свої перспективи розвитку 3 прогнозним розвитком України на середньос- 
троковий і довгостроковий терміни [4, с. 3134]. I тут слід передбачати різні сценарії розвитку, починаючи від оптимістичного i, закінчуючи, певними колапсами, що породжують нерівність доходів; стагнацію малого і середнього бізнесу; відсутність дії мультиплікативного ефекту на економіку, накопичення соціального капіталу і таке інше. Тому задля орієнтування на визначені горизонти соціально-економічного розвитку слід оцінювати і відстежувати індикатори, встановлені у відповідності існуючим світовими топрейтингам, на кшталт індексів, що характеризують [4, с. 63-69]:

1. Свободу, рівність, безпеку, куди входять індекс економічної свободи, світовий індикатор управління, індекс легкості ведення бізнесу та енергетичної безпеки. При цьому кожний індекс вимірюється своїм набором показників, як:

індикатор управління, котрий комплексно оцінює позитивні показники ефективності управління, превалювання (верховенство) права, політичну стабільність та відсутність насилля;

індекс економічної свободи, що характеризує вільний розвиток бізнесу в рамках тих законодавчо-нормативних обмежень, що встановлені в країні;

індекс легкості ведення бізнесу, що визначається показниками, котрі мають відношення до стимулювання, мотивації та трудомісткості господарської діяльності будьякого суб'єкта;

індекс енергобезпеки визначається станом енергозабезпечення, енергетичним балансом; рівнем охорони навколишнього середовища, використанням зеленої енергетики та кращої світової енергетичної практики.

2. Життя, здоров'я, добробуту, що характеризується індексами щастя, людського розвитку, здоров'я та добробуту, де:

індекс щастя вимірюється за показниками тривалості життя; рівня доступу до природних ресурсів, що дозволяють забезпечувати довге, щасливе життя та стану навколишнього середовища;

індекс людського розвитку визначається за показниками, що характеризують не тільки економічний рівень розвитку країни (регіону), але й демографічну ситуацію, котра впливає на зростання людського і соціального капіталу підприємств; індекс здоров'я, що являє собою інтегральну оцінку за показниками тривалості життя, смертності, ефективності використання заходів щодо охорони здоров'я завдяки означенню витрат на якісне медичне обслуговування і рівня доступності усіх категорій населення до цих послуг;

індекс добробуту, що визначається не тільки доходами на душу населення, але й наявністю певного рівня інноваційного потенціалу економіки, що дозволяє створювати додану вартість людського й соціального капіталу;

3. Науки, освіти і культури, котрий вміщує в себе глобальні індекси креативності, інноваційної та зростання патентної активності. Усі ці індекси вимірюється за показниками рівня освіти, культури, інноваційного розвитку та якісного професійного зростання людського й соціального капіталу; умов реалізації та гнучкої трансформації інноваційного потенціалу суб'єктів господарювання.

Методики оцінювання зазначених індексів розроблені різними міжнародними рейтинговими, фінансовими, освітніми установами та організаціями, фондами, всесвітніми економічними форумами, державними та урядовими об'єднаннями [4, с. 5, 65-67]. Тому за показниками, що входять в розрахунок різних індексів, слід відстежувати, контролювати та обліковувати діяльність суб'єктів господарювання. Бо саме вони визначають досягнутий рівень соціально-економічного розвитку та дозволяють ідентифікувати фінансові результати діяльності відповідно до існуючих світових норм, стандартів і рівнів життєздатності, спроможності до інноваційного розвитку і подальшого трансформування суб'єктів господарювання.

В залежності від пріоритетів соціально-економічного розвитку, які ставить перед собою суб'єкт господарювання, можуть вибиратися певні показники, за якими слід відстежувати та здійснювати облік згідно фінансово-статичній звітності. Так, більшість зарубіжних дослідників і практиків [5, с. 2 - 10] доводять, щодо переліку цих показників слід включити ті, що:

характеризують у динаміці ключові індикатори ефективності: фінансові, нефі- 
нансові та комбіновані (про це констатують $82 \%$ - $85 \%$ опитаних респондентів, котрі $\epsilon$ представниками бізнесу різних країн, починаючи від Європи, Америки та Канади й, закінчуючи країнами Африки та Ближнього Сходу);

різні рівні розвитку бізнесу (відповідно $78 \%$ респондентів);

відповідальність щодо здійснюваної діяльності (75\%);

зв'язки (прямі і зворотні) щодо досягнення стратегічних цілей та ініціатив (72\%); систему мотивацій та стимулювання, котра підвищує лояльність усіх співробітників щодо їхньої зацікавленості у стратегічному соціально-економічному розвитку чи досягненні головної місії діяльності суб’єкта господарювання (70\%);

загальні результати діяльності та головні показники місії (65\%);

інші орієнтири, що допомагають визначити подальші перспективи розвитку (57\%).

Причому ці показники можливо контролювати й обліковувати не тільки у стратегічній перспективі, але й в процесі операційної діяльності. Саме моніторинг (контроль та аналіз) негативних операційних відхилень дозволяє оцінювати можливості прогресу у досягненні стратегічних завдань, скорегувати показники, щодо відповідності їх поставленим орієнтирам, та пов'язати ефективність 3 лояльною поведінкою персоналу; скоординувати зв'язки у напрямі роз'яснення та проведення спільної колективної роботи щодо розповсюдження інформації серед зацікавлених стейкхолдерів про успішність й необхідність соціальноекономічного розвитку суб'єктів господарювання.

Існують й інші підходи щодо визначення обліково-фінансових механізмів соціально-економічного розвитку суб'єктів господарювання [6, с. 167-180] та формування показників щодо їх відстеження [7, с. $429,430]$, на кшталт індикаторів оцінювання життєздатності підприємства, як:

а) стійкість, що характеризується коефіцієнтами поточної ліквідності, фінансової незалежності та абсолютної ліквідності.
Ці показники показують взаємодію суб'єктів господарювання із зовнішнім середовищем та його здатність зберігати певну незалежність в рамках означених умов функціонування;

б) надійність, що можна оцінити за рентабельністю власного й основного капіталу, коефіцієнтами оборотності власних коштів, оновленням основних засобів та фондовіддачею. Означений набір показників характеризує здатність досягати поставлені стратегічні (чи поточні) цілі за рахунок власних джерел;

в) живучість, що визначається вартістю інвестицій на одиницю виробництва виробничих потужностей, рентабельністю інвестицій та величиною інвестиційного потенціалу промислового підприємства. Саме ці показники ефективності розвитку інвестицій розкривають усі можливості розкриття та трансформації соціальноекономічного потенціалу суб'єкта господарювання;

г) вмотивованість, котра описується коефіцієнтом повернення інвестицій, прибутковістю та собівартістю на одиницю продукції, рівнем сукупного ризику діяльності. Ці складові формують мотиви і стимули щодо забезпечення відповідності ситуації рівню соціально-економічного розвитку оточуючого середовища.

Загалом суб'єкти господарювання можуть зосередитись на виборі різних орієнтирів соціально-економічного розвитку. Тому на рисунку 1 представлений обліковофінансовий механізм, котрий у своєму складі має різні важелі, що можна застосувати в рамках будь-якого суб'єкта господарювання.

Запропонований склад механізму соціально-економічного розвитку дозволить зосередитись на контролі та обліку головних орієнтирів, що визначають зацікавленість та ефективну діяльність суб'єкта господарювання, та оцінити тенденції його стійкого соціально-економічного розвитку відповідно до загальновизнаних міжнародних стандартів, норм і рівня життєздатності національної економіки. 


\begin{tabular}{|c|c|}
\hline $\begin{array}{l}\text { Формування сис- } \\
\text { теми показників } \\
\text { ппя вілстеження }\end{array}$ & $\begin{array}{l}\text { Ідентифікація показників відповідно фінансово-облікової звітності; } \\
\text { Систематизація показників за різними критеріями оцінювання; } \\
\text { Формування порівняльних таблиць щодо досягнення поставлених цілей }\end{array}$ \\
\hline $\begin{array}{l}\text { Моніторинг } \\
\text { визначених } \\
\text { орієнтирів }\end{array}$ & $\begin{array}{l}\text { Визначення сильних й слабких сторін розвитку; } \\
\text { Налагодження системи контролю та попередження відхилень; } \\
\text { Сортування релевантних заходів щодо нівелювання виявлених негативів }\end{array}$ \\
\hline $\begin{array}{l}\qquad \\
\text { Мотивування та } \\
\text { стимулювання } \\
\text { поставлених шілей }\end{array}$ & $\begin{array}{l}\text { Боротьба з негативами за рахунок стимулювання лояльності персоналу; } \\
\text { Створення системи стимулювання для розв'язання означених задач; } \\
\text { Перевірка відповідності поставлених орієнтирів інтересам зацікавлених } \\
\text { осіб }\end{array}$ \\
\hline $\begin{array}{l}\text { Корегування та } \\
\text { зміна орієнтирів }\end{array}$ & $\begin{array}{l}\text { Оцінювання змін у внутрішньому та зовнішньому середовищі суб’єктів; } \\
\text { Виявлення стійких тенденцій розвитку та формування стабільних } \\
\text { зв’язків і комунікацій щодо подальшого розвитку }\end{array}$ \\
\hline $\begin{array}{l}\text { Управління } \\
\text { соціально- } \\
\text { економічним } \\
\text { розвитком }\end{array}$ & $\begin{array}{l}\text { Застосування інновативних технологій щодо контролю, обліку показників; } \\
\text { Скорочення розривів між соціально-економічними орієнтирами розвит- } \\
\text { ку в порівнянні з європейськими стандартами; } \\
\text { Удосконалення управління соціально-економічним розвитком в процесі } \\
\text { отримання нових фінансово-облікових знань }\end{array}$ \\
\hline
\end{tabular}

Рисунок 1 - Склад обліково-фінансового механізму соціально-економічного розвитку суб'єктів господарювання Джерело: розроблено автором

Висновки та перспективи подалыших досліджень. Підводячи підсумок проведеним дослідженням можна означити такі важливі важелі, котрі слід враховувати в обліковофінансовій діяльності суб'єктів господарювання при визначенні дієвих механізмів сучасного соціально-економічного розвитку:

1. Формування системи обліку фінансово-економічних показників, за якими визначається позитивний темп розвитку суб'єктів та оцінюється ефективність їхньої діяльності.2. Запровадження моніторингу та оцінювання розривів, що виникають між орієнтирами, що відповідають цілям тактичного, i поставленій меті стратегічного розвитку.

3. Врахування масштабів впливу інноваційних дифузій на напрями соціальноекономічного розвитку суб'єктів господарювання та необхідність налаштування на нові мотиви й стимули трансформування національної економіки під впливом розвитку глобальних соціально-економічних систем.

4. Оцінювання наслідків впливу оточуючого середовища на соціально- економічний розвиток суб'єктів господарювання, розробка заходів щодо корегування та зміни орієнтирів відповідно досягненням економіки знань, цифровізації суспільних комунікацій та зацікавленості суб'єктів.

5. Управління інноваційною рефлексією соціально-економічного розвитку суб'єктів господарювання шляхом застосування різних стратегічних та тактичних заходів щодо формування стійких інновативних зв'язків в умовах нестабільного оточуючого глобального середовища.

Подальші дослідження будуть спрямовані на пошук та удосконалення сучасних інформаційно-комунікаційних технологій щодо інноваційної дифузії, надбання та розповсюдження найкращих облікових практик та фінансових оцінювань результатів соціально-економічного розвитку суб'єктів господарювання в умовах постійно змінюваних знань. 


\section{Література}

1. Вугальтер А. Л. Фундаментальная экономия. Динамика. Москва: ЗАО «Издательство «Экономика», 2007. $371 \mathrm{c.}$

2. Смит А. Исследование о природе и причинах багатства народов. Москва: Соцэкгиз, 1962. Режим доступу: https://www.gumer.info/bibliotek_Buks/Econom /smit/smit_1.pdf

3. Гессен Д.О. Еріксен Т. Г. Біг на місиі: парадокси конкуренції. Пер. 3 норвезьк. I. Caбор. Київ: Ніка-Центр, 2014. 208 с.

4. Україна 2030: Доктрина збалансованого розвитку. Львів: Кальварія, 2017. - 168 с.

5. Лоусон Раєф, Дезрочес Деніс, Хітч Тобі Збалансована система показників - краща практика. Розробка, впровадження і оиін$\kappa a$. Пер. $з$ англ.; за наук. ред. А. М. Гершуна. Дніпропетровськ: Баланс Бізнес Буксб 2015. $208 \mathrm{c}$.

6. Проблеми розвитку фінансової системи Украӥни та шляхи їх вирішення: монографія / М.I. Карлін, І.В. Шульга, А.В. Кулай та [iн.]; за ред. д-ра екон. наук, проф. М.I. Карліна. - Луцьк: Вежа-Друк, 2014. - 364 с.

7. Білопольский М. Г., Андрющенко I.C. Концептуальні положення щодо життєздатності підприємств промислового сектору економіки України. Модернізація та структурна трансформачія соціально-економічної системи України: комунальна контента організації обслуговування промислового підприємства: монографія / За заг. ред. О.В. Покатаєвої, Г.Ю. Кучерової. Запоріжжя: КПУ, 2015. С. 423-431.

Стаття надійшла

до редакції : 05.02.2020 p.

\section{References}

1. Vugalter, A. L. (2007). Fundamental economy. Dynamics. Moscow: Publishing house "Economy", 371.

2. Smith, A. (1962). An Inquiry into the Nature and Causes of the Wealth of Nations. Moscow: Socecgiz. Retrived from: https://www.gumer.info/bibliotek_Buks/Econom /smit/smit_1.pdf

3. Hessen, Dag O., Eriksen, Thomas Hylland. (2014). Hurried in place: paradoxes of competition. Kyiv: Nik-center, 208.

4. Ukraine 2030: Doctrine of the balanced development (2017). Lviv: Kalvaria, 168.

5. Lowson, Raef, Desroches, Denis and Hatch, Toby (2015). Scorecard Best Practices. Design, Implementation, and Evaluation. Dnipropetrovsk: Balance Business of Books, 208.

6. Karlin, M.I., Shulga, I.V., Kulai, A.V. and [other] (2014). Problems of development the financial system of Ukraine and ways of their decision. By Ed. Karlin I.V. Lutsk: Tower-printing, 364.

7. Bilopolskyi, M. G., Andriustchenko, I. S. (2015). Conceptual positions in relation to viability of industrial enterprises the sector of Ukraine economy. Modernization and structural transformation of Ukraine socio-economic system: communal content of organizations of maintenance the industrial enterprise. By Ed. O.V. Pokataeva, G.Yr. Kucherova. Zaporizhzhya: CPU, 423-431.

Стаття прийнята

до друку: 30.03.2021 p.

Бібліографічний опис для цитування :

Калінеску Т. В. Обліково-фінансові механізми соціально-економічного розвитку суб'єктів господарювання / Т. В. Калінеску // Часопис економічних реформ. - 2021. № 1(41). - С. 50-57. 